\title{
The Effectiveness of Know, Want to Know, Learned Plus Strategy in Exposition Writing Instruction
}

\author{
Dian Nurvita Sari* \\ Graduate School \\ Universitas Negeri Yogyakarta \\ Yogyakarta, Indonesia \\ dian.nurvita2016@student.uny.ac.id
}

\author{
Kastam Syamsi \\ Graduate School \\ Universitas Negeri Yogyakarta \\ Yogyakarta, Indonesia \\ kastam@uny.ac.id
}

\begin{abstract}
This research aimed to examine (1) there was a significant difference in the ability to write expository texts between students who took learning by implementing the KWL Plus strategy and students who took conventional learning; and (2) the effectiveness of KWL Plus strategy in writing exposition learning. This was a quasi experiment research with a Pretest - Posttest Control Group Design. The instrument validity was aimed for content validity which was gained through expert judgement. The analysis of the requirement test analysis used a normality test and homogeneity variant test. The data analysis was conducted using t-test. The result showed that (1) there was a significant difference between KWL Plus strategy and conventionally strategy in writing exposition learning; and (2) learning using KWL Plus strategy was likely more effective than learning exposition conventionally.
\end{abstract}

Keywords—writing, exposition, KWL Plus

\section{INTRODUCTION}

Writing as one of the language skills aims to transform the writer's ideas into written form. Writing is an activity that demands cognitive and complex elements (Martens, 2010:3). It shows that good writing skills are not obtained automatically, but it need a training process. One implementation of writing skills in learning Indonesian language at school is writing exposition text. Lexically, exposition comes from the English word exposition, which means to open. Terminologically, expository essay is an essay that aims to inform, explain, peel, and describe something (Jauhari, 2013: 58).

Knaap and Watkins (2005: 191) state that in school, learning to write an argumentation text is focused into two types, they are exposition and discussion. In other words, the exposition text belongs to the genre of argument text. In studying argumentation text, Knaap and Watkins (2005: 191) suggest to start with exposition because it is a type of text that clearly focuses students' attention on the purpose of argumentation, so that they will express their views and provide assistance to support it.

In exposition writing activities, the most common constraints experienced by students are the difficulty of focusing on the main topic, finding the points of information that are needed to compose the exposition text, and finding the right solution to the problem in the exposition text that will be created.

Learning to write exposition texts in schools so far has been carried out conventionally, which is in accordance with the current 2013 curriculum. The steps outline are as follows, the teacher gives examples of text, does questions and answers briefly with students about learning material, students look for sources of information themselves, asks students to write down the points of information they will write, then students are asked to practice writing. It occurs because the teacher does not know an effective strategy in learning to write an exposition text. Therefore, the research is needed to test the effectiveness of learning strategies for writing exposition text learning. The strategies to be tested for effectiveness are Know, Want to Know, Learned Plus (KWL Plus).

The KWL Plus strategy is a technique that helps students review what they already know before they begin a reading assignment. This strategy will help them to make predictions about what they will read by using questions. The strategy also helps students to organize what they have learned when they have finished reading (Carr and Ogle via Buehl, 2000: 75). Besides, this strategy also can be used for learning to write because it can help students to get their writing information points, especially at the Know, Want to Know, and Learned stages. In addition, this strategy can also help students to organize their writing because before writing, precisely at the Plus stage, students are asked to make a concept map first (Buehl, 2000: 75). It will make students' writing more focused and systematic.

In applying the KWL Plus strategy before reading activity, students explore the initial knowledge they already have and determine what they want to learn. After reading, they remember what they have learned as a result of reading. KWL Plus helps students to activate their prior knowledge and gives them the opportunity to reflect on and manage what they have learned from reading about a topic. Students focus on what is important in the text to develop their understanding (Wiesendanger, 2000: 100-102).

KWL Plus is a strategy that can help students to explore the knowledge they already know, give them the opportunity to consider and search for things they do not know before, then understand them. After understanding the topic, students create a concept map as their writing framework. 
Here are the advantages of the KWL Plus strategy, that is (1) it provides teachers with an inventory of students background knowledge about a topic; (2) students have a structure for making predictions about what they will read; (3) students develop the self-questioning skills and learn to read actively to answer their questions about a topic; (4) students are guided into meaningful of new information; and (5) students misconceptions about topic are revealed and addressed during instruction (Buehl, 2000: 76).

KWL Plus is one of the strategies that must be taught thoroughly to make material learning interesting. This strategy can be used to encourage students connection between their prior knowledge and new information so as to facilitate construction of meaning (Shelly, et al, 1997: 241). Fengjuan (2010) in his research found that KWL has been proven to work as an effective strategy in achieving the goal ultimate all round development in the ability to listen, speak, read, write and interpret students.

Meanwhile, Wagner (2014) on his thesis, reinforces the effectiveness of KWL Plus strategy writing instruction, that is in writing science journals. The results of this research indicated that the KWL Plus strategy influences understanding of content knowledge. The results showed that KWL Plus was an effective tool for formative assessment. The KWL Plus strategy could be expanded to enrich student questions, potentially helped students learn English, and potentially be used by students without depending on the teacher.

There are six steps in implementing this strategy, they are (1) students write down what they know or think they know about the topic. Students take note what they know about the topic in the first column K (Know); (2) students take note the questions or things they want to know in the middle column of W (Want to Know); (3) the teacher guides students in grouping their knowledge and questions; (4) students read stories or other sources to find information to answer their questions or increase their understanding of the topic; 5) students fill in column L (Learned) which contains the things those students have learned; and (6) students create concept maps and then develop them into exposition texts. The steps of implementing the KWL Plus strategy are summarized in the KWL Plus format, consisting of the Know, Want to Know, Learned and Plus columns. According to Wiesendanger's theory (2000: 100-102), KWL Plus is a three step procedure that can be used in expository texts involving basic cognitive steps.

The KWL Plus strategy will be tested for students' effectiveness in learning of exposition text writing in grade $X$ students of SMA Negeri 1 Minggir. Theoretically, this strategy can make the learning easier for students to find the points of information and to focus in arranging exposition texts on their writing, and students' writing will be more systematic. It can improve students' ability to write an exposition text.

\section{RESEARCH METHOD}

The research employed a quantitative quasiexperimental research with a pretest-posttest control group design. The two variables in this research were the use of the KWL Plus strategy in learning to write exposition text as the independent variable and the ability to write exposition text as the dependent variable.

This research was conducted at SMA Negeri 1 Minggir grade X. The research was conducted on October 17, 2018 to November 8, 2018. The populations in this research were all students of grade X SMA Negeri 1 Minggir which consisted of four classes. The sample in this research was class X MIPA 1 as an experimental group and class X IPS 1 as a control group. The sampling step in this research used random sampling technique.

The procedure in this research consisted of (1) the stage before the experiment, at this stage a pretest writing the exposition text was done to the experimental and control experimental group. The purpose of this pretest was to know the students' initial ability before learning to write exposition text; (2) the experimental stage, at this stage the experimental group 1 and the control were given learning treatment to find out the increased ability to write exposition text. The experimental group 1 was treated by applying the KWL Plus strategy, while the control group was treated by using conventional learning; and (3) the stage after the experiment, at this stage the experimental and control groups were given a posttest to write the exposition text. The purpose of this post-test was to know the achievement of increasing the ability to write exposition text in the two research groups, to know whether there was a difference between students who were treated with the KWL Plus strategy and students who followed conventional learning.

The instrument which was used in this experimental research was in the form of a performance test for exposition text writing and an observation sheet for treatment. Scoring data obtained from the instrument would be used as analysis material. The aspects assessed in the student exposition text in accordance with the assessment criteria included content, organization (presentation and completeness of the exposition text structure), use of language, and mechanics. The validity used in this research was the content validity by the expert (expert judgment). After content validity testing was done, this research instrument was declared feasible to use. Reliability testing was carried out in groups other than the research group. After obtaining the data, the data was analyzed using the Cronbach Alpha formula. An instrument would be reliable if the reliability was greater than $0.6(r>0.6)$. The following were the results of calculating the reliability of the instrument.

TABLE 1. THE TEST RESULTS OF EXPOSITION TEXT WRITING INSTRUMENTS

\begin{tabular}{|c|l|c|}
\hline Alpha Cronbach & $\begin{array}{l}\text { Alpha Cronbach Based on } \\
\text { Standardized Items }\end{array}$ & N \\
\hline 0.799 & 0.825 & 5 \\
\hline
\end{tabular}

The data analysis technique used in this research was the t-test which included free samples t-test and paired samples t-test. Free sample t-test was conducted to prove whether there was a difference in the ability to write exposition text between students in the experimental group and the control group, while the paired sample t-test was conducted to prove the effectiveness of the KWL Plus 
strategy in learning to write exposition text in the experimental group.

Before analyzing the data using the t-test, the prerequisite test for data analysis was performed using the data distribution normality test and the variance homogeneity test. Data distribution normality test was conducted to test the normality of data distribution value of the ability to write exposition text in the two research groups, while the variance homogeneity test was performed to determine whether the sample from the population had the same variant or did not show significant differences. All calculations related to data analysis were performed with the help of the SPSS version 21.0 computer program.

\section{RESEARCH RESULTS AND DISCUSSION Research Results}

The data in this research included data on initial test scores obtained through pretest and final test score data which was obtained through posttest. The comparison of the data values of the ability to write the text of the exposition control group and the experimental group were presented in the following table

TABLE 2. THE COMPARISON OF CAPABILITY OF WRITING TEXT EXPOSITION SCORING DATA BETWEEN EXPERIMENTS AND CONTROL GROUPS

\begin{tabular}{|l|c|c|c|c|}
\hline \multirow{2}{*}{ Data } & \multicolumn{2}{c|}{ Pretest } & \multicolumn{2}{c|}{ Posttest } \\
\cline { 2 - 5 } & Experiments & Control & Experiments & Control \\
\hline N & 31 & 30 & 31 & 30 \\
\hline Highest Score & 87 & 83 & 88 & 82 \\
\hline Lowest Score & 61 & 60 & 77 & 67 \\
\hline Average Score & 72.32 & 72.53 & 83.65 & 75.43 \\
\hline Median & 71 & 72 & 83 & 76 \\
\hline Modus & 64 & 72 & 83 & 77 \\
\hline Standard Deviation & 7.652 & 6.410 & 2.893 & 4.023 \\
\hline
\end{tabular}

Before the analysis was performed, the prerequisites were tested prior to the data distribution normality test and variant homogeneity test were conducted. Data distribution was stated to have a normal distribution if the $\mathrm{p}$ value obtained from calculations was greater than 0.05 (significance level of 5\%). The following table showed the results of normality test data distribution scoring of the ability to write exposition text.

TABlE 3. The Normality Test RESUlts OF DATA Distribution OF SCORE ABILITY TO WRITE TEXT EXPOSITION EXPERIMENTS AND CONTROL GROUPS

\begin{tabular}{|l|l|c|c|c|}
\hline No. & \multicolumn{1}{|c|}{ Data } & $\begin{array}{c}\text { Kolmogoro } \\
\text { Smirnov }\end{array}$ & Sig & Note \\
\hline 1 & Pretest Experiments & 0.117 & 0.200 & $\mathrm{p}>0.05=$ normal \\
\hline 2 & Pretest Control & 0.111 & 0.200 & $\mathrm{p}>0.05=$ normal \\
\hline 3 & Posttest Experiments & 0.147 & 0.086 & $\mathrm{p}>0.05=$ normal \\
\hline 4 & Posttest Control & 0.118 & 0.200 & $\mathrm{p}>0.05=$ normal \\
\hline
\end{tabular}

Homogeneity test of variance was carried out after testing the normality of data distribution. The data was stated as homogeneous if the significance value of the calculation results was greater than the specified significance level, which is $0.05(5 \%)$. The following table showed the homogeneity test results of the data variant writing exposition text.

TABle 4. Homogeneity Test Results of DATA VARIANTS WRITING EXPOSITION TEXTS EXPERIMENTS AND CONTROL GROUPS

\begin{tabular}{|c|c|c|c|c|c|}
\hline No. & Data & $\begin{array}{c}\text { Levene } \\
\text { Statistic }\end{array}$ & Df1 & Df2 & Sig. \\
\hline 1 & Pretest & 1.878 & 1 & 59 & 0.176 \\
\hline
\end{tabular}

\begin{tabular}{|l|l|l|l|l|l|}
2 & Posttest & 3.766 & 1 & 59 & 0.057 \\
\hline
\end{tabular}

Table 3 and Table 4 showed that the data distribution exposition text writing was normal and it had a homogeneous variant. It showed that the data was feasible to analyze.

After the data was stated as feasible to be analyzed, data analysis was performed. Data analysis in this research used t-test calculations which included free sample t-tests and paired sample t-tests. Data requirements were significant if $\mathrm{t}_{\text {count }}$ is greater than $\mathrm{t}_{\text {table }}$ and $\mathrm{p}$ value was smaller than the error level of $0.05(5 \%)$.

Table 5. Pretest Data T-Test Results of Exposition TeXts Ability TEST OF EXPERIMENTS AND CONTROL GROUPS

\begin{tabular}{|l|c|c|c|c|c|}
\hline \multicolumn{1}{|c|}{ Data } & $\mathbf{T}_{\text {count }}$ & $\mathbf{D f}$ & $\mathbf{t}_{\text {table }}$ & $\mathbf{P}$ & \multicolumn{1}{c|}{ Note } \\
\hline $\begin{array}{l}\text { Pretest } \\
\text { Experiments and } \\
\text { Control }\end{array}$ & 0.116 & 59 & 2.001 & 0.908 & $\mathrm{~T}_{\text {count }}<\mathrm{t}_{\text {table }} \neq$ Significant \\
$\mathrm{p}>0.05 \neq$ Significant
\end{tabular}

Table 5 showed that there was no significant difference in the ability to write exposition text between the experimental group and the control group before being treated because the $t_{\text {count }}$ was smaller than the $t_{\text {table }}$ and the $p$ value was greater than 0.05 error level.

The results of the free sample t-test for the posttest data of learning to write the exposition text of the experimental group and the control group were presented in the following table.

TABle 6. Posttest Test Results of CAPABility of Writing TeXt EXPOSITION DATA OF EXPERIMENTS AND CONTROL GROUPS

\begin{tabular}{|c|c|c|c|c|c|}
\hline Data & $\mathbf{T}_{\text {count }}$ & Df & $\mathbf{t}_{\text {table }}$ & $\mathbf{P}$ & Note \\
\hline \multirow{2}{*}{$\begin{array}{l}\text { Posttest Experiments } \\
\text { and Control }\end{array}$} & \multirow[b]{2}{*}{9.176} & \multirow[b]{2}{*}{59} & \multirow[b]{2}{*}{2.001} & \multirow[b]{2}{*}{0.000} & $T_{\text {count }}>t_{\text {talel }}=$ Significant \\
\hline & & & & & $\mathrm{p}<0.05=$ Significant \\
\hline
\end{tabular}

Table 6 shows that there was a significant difference in the ability to write exposition texts between the control and experimental groups after treatment because $t_{\text {count }}$ was greater than $t_{\text {table }}$ and $p$ value was smaller than the level of error.

After the free sample t-test was done, and then the paired sample t-test was performed. The results of the sample t-test related to the pretest and posttest data of the experimental group's exposition text could be seen in the following table.

TABLE7. T-Test Results of SCORING Data of Pretest And PostTest IN EXPOSITION TEXTS WRITING TEST FOR EXPERIMENTAL GROUP

\begin{tabular}{|l|c|c|c|c|l|}
\hline \multicolumn{1}{|c|}{ Data } & $\mathbf{t}_{\text {count }}$ & Df & $\mathbf{t}_{\text {table }}$ & $\mathbf{P}$ & \multicolumn{1}{|c|}{ Note } \\
\hline $\begin{array}{l}\text { Scoring Data of } \\
\text { Experimental } \\
\text { Group }\end{array}$ & 8.039 & 30 & 2.042 & 0.000 & $\begin{array}{l}\mathrm{t}_{\text {count }}>\mathrm{t}_{\text {table }}= \\
\text { Significant }\end{array}$ \\
\cline { 5 - 6 } & & & $\begin{array}{l}\mathrm{p}<0.05= \\
\text { Significant }\end{array}$ \\
\hline
\end{tabular}

Table 7 shows that there were significant differences in the ability to write exposition texts in the experimental group students before and after learning because the $t_{\text {count }}$ was greater than $t_{\text {table }}$ and the p-value was smaller than 0.05 error level.

The results of the sample t-test related to the pretest and posttest data writing the exposition text of the control group could be seen in the following table.

TABle 8. T-Test Results of SCORING DATA of PRETEST AND PostTEST IN EXPOSITION TEXTS WRITING TEST FOR CONTROL GROUP

\begin{tabular}{|c|c|c|c|c|c|}
\hline Data & $\mathbf{T}_{\text {count }}$ & Df & $\mathbf{t}_{\text {table }}$ & $\mathbf{P}$ & Note \\
\hline Scoring Data & 3.027 & 29 & 2.045 & 0.005 & $\mathrm{~T}_{\text {count }}>\mathrm{t}_{\text {table }}=$ \\
\hline
\end{tabular}




\begin{tabular}{|l|l|l|l|l|l|}
\hline of Control & & & & & Significant \\
\cline { 3 - 3 } & & & & & $\begin{array}{l}\mathrm{p}<0.05= \\
\text { Sroupificant }\end{array}$ \\
\hline
\end{tabular}

Table 8 showed that there was a significant difference in the ability to write exposition texts in the control group students before and after learning because $t_{\text {count }}$ was greater than $t_{\text {table }}$ and $\mathrm{p}$ value was smaller than the error level 0.05.

T-test samples related to the pretest and posttest data of the two groups showed significant results. Although equally significant, the experimental group was shown to experience a greater increase in mean values. This is the evident from the statistical data that showed that the experimental group experienced an average increase of 11.33, while the control group experienced an average increase of 2.90 .

The following were the results of hypothesis testing based on the results of data analysis of the ability to write an exposition of the control group and the experimental group.

\section{a. First Hypothesis Test Results}

There was a significant difference in the ability to write expository texts between students who took learning by implementing the KWL Plus strategy and students who took conventional learning.

\section{b. Second Hypothesis Test Results}

Learning of exposition text writing using the KWL Plus strategy was more effective compared to learning of conventional exposition text writing.

\section{B. DISCUSSION}

\section{Differences in the Ability of Exposition Writing Between} the Experimental Group and The Control Group

Based the t-test calculation of free samples on the posttest data writing ability of exposition text could be concluded that there was a significant difference in the ability to write expository texts between students who took learning by implementing the KWL Plus strategy and students who took conventional learning.

In this research, experimental and control group experienced a significant ability to write exposition text, however the experimental group was shown to experience a greater increase in mean values. This was the evident from the statistical data that showed that the experimental group experienced an average increase of 11.33 , while the control group experienced an average increase of 2.90. This showed that there were significant differences in the ability to write exposition texts in the two groups.

The difference in the ability to write exposition texts between the control and experimental groups were due to differences in treatment. The experimental group was treated by applying the KWL Plus strategy, while the control group was treated with conventional strategies.

The group treated with the KWL Plus strategy was shown to have the ability to write exposition text better than conventional strategies because students were requiring to bring back their initial knowledge, making predictions about what they wrote, making it easier to organize their writing by making concept maps, making their writing more systematic and focused. It was in accordance with Carr and Ogle's theory (via Buehl, 2000: 75) which states that the KWL Plus strategy is a technique that helps students review what they already know before they begin a reading assignment. By using this strategy, it would help students to make predictions about a topic which would be taught from the questions. The strategy also helped students to organize what they had learned after they had finished reading. This strategy could also be used for writing learning because it could help students to get their writing information points. In addition, this strategy could also help students to organize their writing because before writing, students were asked to make a concept map first. It would make student writing more focused and systematic.

In the experimental and control groups, the students were given posttests that were carried out after the two study groups participated in the four learning treatments. The posttest was conducted to obtain data to be analyzed to determine differences in learning outcomes for writing exposition text in the two research groups. The posttest in this research was in the form of essay questions of writing exposition text. Each student wrote exposition text with a free topic.

The control group also experienced an increase because it had been through learning four times. Four times learning allowed students to develop their ability to write exposition text by learning from mistakes made in the previous treatment. These errors were mostly in the spelling and mistakes of word selection.

If related to previous research which conducted by Herlina, Yufrizal, and Hasan (2013) entitled "Teaching Writing Through KWL (Know, Want to Know, and Learn) Technique at the Second Year of MAN 1 Bandar Lampung", this research showed the same results in the form of an increase in the ability to write exposition text in groups of students who took part in learning by applying the KWL Plus strategy. The difference, this research only used one research group. There were six meetings in the research. This research used three topics in writing exposition text. The result is an increase in the average value on topics I, II, and III are 15.42, 14.91, and 16.48. Meanwhile, the increase in the percentage of students who passed the minimum criteria of mastery learning was $61.97 \%, 43.90 \%$, and $53.66 \%$. This showed that increasing the ability of students to write exposition (hortatory exposition) was good.

In addition, the research conducted by Herlina, Yufrizal, and Hasan (2013) also showed that after six meetings, there was an increase in students' ability to write exposition texts, the most dominant increase was on the aspects of content, vocabulary, and language use. The difference, in this research, the dominant increase occurred in aspects of spelling and word selection.

\section{The Superiority of the KWL Plus Strategy in Exposition Writing Learning}

The effectiveness of the KWL Plus strategy in learning to exposition writing could be known by looking at the results of the t-test calculation of the increase in the pretest and posttest value of learning to write the exposition text in the experimental group. The t-test calculation results showed that the KWL Plus strategy was effectively used in exposition writing learning. 
In learning to write exposition text, the KWL Plus strategy is technique that helped students review what they already know before they begin to do an assignment and give them the opportunity to reflect on and manage what they had learned from reading about a topic. According to the theory, through this strategy students' misunderstanding of a topic can be known and discussed during learning (Buehl, 2000: 75). It would certainly increase student understanding.

The steps for implementing the KWL Plus strategy were summarized in the KWL Plus format, consisting of the Know, Want to Know, Learned and Plus columns. It is in accordance with the Wiesendanger's theory (2000: 100-102) which says that KWL Plus is a three step procedure that can be used in expository texts involving basic cognitive steps. In the first step, students wrote down what they knew about the topic they are going to write. Students noted what they know about the topic in the first column $\mathrm{K}$ (Know). In this research, students were able to explore their initial knowledge of the topic they were about to write. This was consistent with the theory that the KWL Plus strategy able to encourage students to make connections between prior knowledge and new information so as to facilitate the construction of meaning (Shelly, et al, 1997: 241). In addition, in this research, at coloum K (Know) the teacher could find out a list of students' knowledge about the topic they are going to write. This is according to Buehl's theory (2000: 76) which states that this strategy can also give the teacher a list of knowledge students have about a topic (Buehl, 2000: 76). After that, students prepared to read examples of exposition texts and references from various sources about the topics they would write.

In the second step, students wrote down questions or things they wanted to know in the middle column of $\mathrm{W}$ (Want to Know). Then, the teacher guided students in grouping their knowledge and questions. Students noted it in a table entitled Information Categories. After that, the teacher guided students to observe examples of exposition texts and read various sources to find information to answer students' questions or increased their understanding of the topic. It is in accordance with the theory that one of the advantages of the KWL Plus strategy is that students can develop self-questioning skills and learn to read actively to answer their questions about a topic (Buehl, 2000: 76). In addition, this is also in accordance with Wiesendaner's theory (2000: 100) that this strategy makes students learn to ask questions that are meaningful to help improve their own understanding and develop their ability to actively read and understand expository.

In the third step, when students had finished reading, the teacher guided students to focus on the third column L (Learned). Column L contained the things that students had learned. Students wrote new information that they find in the column L. The students can find out about the topic from various sources. They would be guided to compile meaningful new information. At this stage, according to the theory which says that through the implementation of the KWL Plus strategy, students will be guided into the compilation of meaningful new information (Buehl, 2000: 76).
The next step was the Plus stage. This stage was the stage that distinguishes ordinary KWL strategies from KWL Plus strategies. The ordinary KWL strategy could only be used for learning to read, whereas the KWL Plus strategy was developed so that it could be used in learning to read and write. When the KWL Plus table was complete, students created a concept map that carries all information in each category. Creating this concept map could be done individually. This concept map was used as an assignment framework for exposition text writing. After the concept map had finished, students write an exposition text (Buehl, 2000: 75).

Based on the analysis of research results, this strategy had proven to be effective in applying exposition text writing learning compared to applying conventional strategies because the steps in the KWL Plus strategy could further assist students in writing. The steps in the KWL Plus strategy could help students regain their initial knowledge, make predictions about what they write, make it easier to organize their writing by making concept maps, make their writing more systematic and focused. Meanwhile, the conventional strategies used by the teacher so far in learning to write exposition text only focus on students who were asked to observe examples of explanatory texts, asked questions if there were questions, sought information from various sources freely, and wrote directly.

If related to previous research, the results of this research are consistent with research conducted by Herlina, Yufrizal, and Hasan (2013). The text used as data in this research is hortatory text exposition. Based on the writing components used, the results of these tests indicate that the KWL Plus strategy was effective for learning to write exposition hortatory texts. This research concluded that increasing the ability of students to write exposition hortatory texts was good. In addition, in this research the most dominant increase in students was seen in the component content, vocabulary, and language use. The results of Herlina, Yufrizal, and Hasan's (2013) research are in accordance with this research, KWL Plus strategy was effectively used in learning to write exposition texts because it could improve students' writing abilities.

This research is also in accordance with research conducted by Wagner (2014) entitled "Integrating KWL Prompts into Science Journal Writing: Can Simple Questions Scaffolding Increase Student Content Knowledge?" In his research, researchers tested the effectiveness of the KWL Plus strategy in one of writing learning, namely in writing scientific journals. Researchers revealed that the KWL Plus strategy influenced students' understanding of the content of their writing. Researchers also believed that KWL Plus was an effective tool for formative assessment. The KWL Plus strategy could be expanded to enrich student questions, potentially help students learn English, and potentially be used by students without depending on the teacher. Wagner's (2014) research results are consistent with this research, KWL Plus strategy is effectively used in learning to write because it is able to improve students' abilities.

Then, this research is also in accordance with research conducted by of Lou, Wu, Liu, and Chen (2016) entitled 
"Improving Non-English-Majored College Students' Writing Skills: Combining a Know-Want-Learn-Plus Strategy of Meta-Cognitive Writing Strategy Instruction and InternetBased Language Laboratory Support ". In this research, researchers combined the KWL Plus strategy with the metacognitive translation instruction strategy and the internet-based language laboratory in an effort to improve the writing skills of non-English students. The results of this research compared to the teacher-dominated approach, this combined strategy was more effective in improving students' writing skills, there were significant differences between the two research groups, and students responded more positively to the combined instructions. The results of Lou, Wu1, Liu, and Chen's (2016) research are in accordance with this research, KWL Plus strategy is effectively used in writing learning because it can improve students' writing abilities.

\section{CONCLUSIONS, IMPLICATIONS, AND SUGGESTIONS}

Based on the results of research, data analysis, and discussion that had been stated, there were two conclusions could be drawn. Firstly, there was a significant difference in the ability to write expository texts between students who took learning by implementing the KWL Plus strategy and students who took conventional learning. Secondly, learning to write exposition using the KWL Plus strategy was more effective than learning to write exposition conventionally.

The KWL Plus strategy was more effective than learning to write exposition conventionally because the steps in the KWL Plus strategy can further assist students in writing. The steps in the KWL Plus strategy could help students regain their initial knowledge, make predictions from questions, make it easier to organize their writing by making concept maps, make their writing more systematic and focused.

The implication of this research was that theoretically this research had proven the effectiveness of the KWL Plus strategy in learning to write exposition. Practically, the results of this research provided evidence that learning to write exposition using the KWL Plus strategy was more effective than learning to write exposition text conventionally, so teachers needed to use this strategy to improve student exposition writing learning outcomes.

Based on the conclusions and implications above, here are some suggestions as an effort to improve the ability to write exposition. First, the KWL Plus learning strategy can be used as an alternative and innovation in learning to write exposition by adjusting the conditions of students in each school. Second, further researchers need to be done on learning to write exposition using other learning strategies. In addition, further researchers need to be done on the use of the KWL Plus strategy to be applied to other writing learning materials.

\section{REFERENCES}

Buehl, D. (2000). Classroom srategies for interactive learning. United States of America: International Reading Association.

Fengjuan. (2010). The integration of the know-want-learn (KWL) strategy into english language teaching for non-english majors. Chinese Journal of Applied Linguistics, 33, 77-86. Retrieved from http://www.celea.org.cn/teic/92/10120605.pdf

Herlina, Yufrizal, H., \& Hasan, B. (2013). Teaching writing through KWL (Know, Want, and Learn) technique at the second year of MAN 1 Bandar Lampung. Jurnal Unila, tidak diterbitkan, Universitas Lampung. $\quad$ Retrieved from https://media.neliti.com/media/publications/193200-EN-teachingwriting-through-kwl-know-want-a.pdf

Jauhari, H. (2013). Terampil mengarang. Bandung: Nuansa Cendekia.

Knapp, P., \& Watkins, M. (2005). Genre, text, grammar. Sidney: NSW.

Lou, Y., Wu, L., Liu, H., \& Chen, L. (2016). Improving non-englishmajored college students' writing skills: combining a know-want-learn plus model of meta-cognitive writing strategy instruction and internetbased language laboratory support. Open Journal of Social Sciences, 4, 37-44. Retrieved from https://www.scirp.org/html/51760994_69887.htm

Martens, N.L. (2010). Writing processes, tools, and techniques. New York: Nova Science Publishers Inc.

Shelly, A.C., Bridwell, B., Hyder, L., Ledford, N., \& Patterson, P. (1997). Revisiting the K-W-L: what we knew; what we wanted to know; what we learned. Reading Horizons, 37, 233-242. Retieved from https://scholarworks.wmich.edu/cgi/viewcontent.cgi?article=1290\&co ntext=reading_horizons

Wagner, B.J. (2014). Integrating $K-W-L$ prompts into science journal writing: can simple question scaffolding increase student content knowledge? (thesis). Retrieved https://www.semanticscholar.org/paper/Integrating-K-W-L-Promptsinto-Science-Journal-Can-

Wagner/fdb6fc32769da43ed80ff97187555b787fe4e7ab

Wiesendanger, K.D. (2001). Strategies for literacy education. Ohio: Merrill Prentice Hall. 